\title{
Kemampuan siswa SMP dalam menyelesaikan soal matematika berbasis HOTS
}

\author{
Myelnawan ${ }^{1, \text { a, } * \text {, Wahyu Setyaningrum }}{ }^{2, \mathrm{~b}}$ \\ ${ }^{1}$ SMP Negeri 1 Papalang \\ Topore, Papalang, Kabupaten Mamuju, Sulawesi Barat 91563, Indonesia \\ ${ }^{2}$ Jurusan Pendidikan Matematika, Universitas Negeri Yogyakarta \\ Jl. Colombo No. 1, Karangmalang, Yogyakarta 55821, Indonesia \\ E-mail: ${ }^{a}$ myelnawan3@gmail.com, ${ }^{b}$ wahyu_setyaningrum@uny.ac.id \\ * Corresponding Author
}

\section{ARTICLE INFO}

\section{Article history}

Received: 23 October 2017

Revised: 10 September 2021

Accepted: 11 Sept. 2021

\section{Keywords}

Kemampuan siswa, pembelajaran matematika, higher order thinking skills, students' ability, mathematics learning

Scan me:

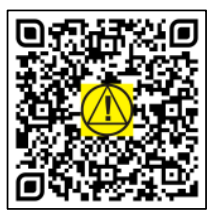

\section{ABSTRACT}

Penelitian deskriptif kualitatif ini bertujuan untuk mendeskripsikan kemampuan siswa SMP di Kabupaten Mamuju dalam menyelesaikan soal matematika berbasis Higher Order Thinking Skills (HOTS). Kemampuan siswa dilihat berdasarkan indikator menganalisis, mengevaluasi, dan mencipta. Subjek penelitian adalah 98 siswa SMP di Kabupaten Mamuju, Indonesia, yang berasal dari empat sekolah dengan kategori tinggi. Pengumpulan data menggunakan tes pilihan ganda, tes uraian, dan wawancara untuk menggali informasi lebih mendalam dari siswa. Hasil penelitian menunjukkan bahwa secara umum kemampuan siswa SMP di Kabupaten Mamuju dalam menyelesaikan soal matematika berbasis HOTS berada pada kriteria rendah. Persentase siswa yang mampu menjawab soal untuk indikator menganalisis termasuk pada kriteria sedang. Sedangkan, persentase siswa yang mampu menjawab soal untuk indikator mengevaluasi dan mencipta termasuk pada kriteria sangat rendah.

This qualitative descriptive study aims to describe the ability of junior high school students in Mamuju Regency to solve mathematics problems based on Higher Order Thinking Skills (HOTS). Students' abilities were seen based on indicators of analyzing, evaluating, and creating. The research subjects were 98 junior high school students from four high-performance schools in Maтuju Regency, Indonesia. Data collection used multiple-choice tests, essay tests, and interviews to dig deeper information from students. The study results revealed that the overall ability of junior high school students in Mamuju Regency in solving mathematics problems based on HOTS was in the low criteria. The percentage of students who could answer questions for analyzing indicators was included in the medium criteria. Meanwhile, the percentage of students who were able to answer questions for indicators of evaluating and creating was included in the very low criteria.

This is an open access article under the CC-BY-SA license.

How to Cite: Myelnawan, M., \& Setyaningrum, W. (2021). Kemampuan siswa SMP dalam menyelesaikan soal matematika berbasis HOTS. Jurnal Riset Pendidikan Matematika, 8(1), 83-95. https://doi.org/10.21831/jrpm.v8i1.16533

\section{PENDAHULUAN}

Standar isi pendidikan dasar dan menengah Indonesia menyebutkan bahwa kompetensi yang diharapkan dari siswa di antaranya menunjukkan sikap logis, kritis, analitis, kreatif, cermat dan teliti, bertanggung jawab, responsif, dan tidak mudah menyerah dalam memecahkan masalah, memiliki kemampuan mengkomunikasikan gagasan matematika dengan jelas, mengidentifikasi pola dan menggunakannya untuk menduga perumuman/aturan umum dan memberikan prediksi, membandingkan, memahami konsep, memberikan estimasi penyelesaian masalah dan membandingkannya dengan hasil perhitungan (Kemendikbud, 2016, pp. 116-118). Dalam rangka mencapai tujuan tersebut, maka pembelajaran matematika sangat perlu mengembangkan berbagai aspek keterampilan di antaranya 
adalah keterampilan berpikir tingkat tinggi (higher order thinking skills atau HOTS). Merangkum berbagai pendapat ahli HOTS adalah keterampilan berpikir yang lebih kompleks meliputi berpikir kritis dan berpikir kreatif untuk menyelesaikan berbagai permasalahan non-algoritmik yang di dalamnya melibatkan kemampuan untuk menganalisis, mengevaluasi, dan mencipta (Brookhart, 2010, p. 5; NCTM, 2000, p. 7; Newmann et al., 2007, p. 35; Pillay et al., 2016, p. 452; Presseisen, 1985, pp. 5859; Resnick, 1992, p. 44; Thomas \& Thome, 2009).

HOTS sangat diperlukan oleh setiap siswa di lingkungan pendidikan, karena: (1) berguna dalam proses pembelajaran; (2) membantu siswa dalam memecahkan masalah dengan lebih baik; (3) meningkatkan kepercayaan diri siswa; (4) meningkatkan prestasi belajar siswa; (5) membantu siswa untuk memanipulasi informasi dan gagasan dengan cara yang mengubah makna dan implikasinya (Brookhart, 2010, p. 9; Butkowski et al., 1994, p. 10; Conklin, 2012, p. 14; Newmann et al., 2007, p. 35; Thompson, 2012, p. 1; Yee et al., 2011, p.121; Yen \& Halili, 2015, p. 42). Salah satu cara untuk meningkatkan kemampuan berpikir dan prestasi siswa adalah dengan menggunakan penugasan dan asesmen yang membutuhkan kemampuan intelektual dan berpikir kritis yang memiliki hubungan dengan peningkatan prestasi siswa. Peningkatan ini ditunjukkan dengan berbagai macam hasil pencapaian seperti hasil ujian dan sebagainya.

Beberapa ahli menyatakan bahwa HOTS erat kaitannya dengan berpikir kritis dan kreatif (Anwar et al., 2012, p. 44; Arend \& Kilcher, 2010, p. 233; Epstein \& Kernberger, 2006, p. 5; Lai, 2011, p. 2; Nitko \& Brookhart, 2011, p. 232; Renstein \& Lander, 1990, p. 80; Orlich et al., 2010, p. 286). Dalam pembelajaran matematika, berpikir kritis dan kreatif sangat membantu peningkatan dan pengembangan HOTS siswa. Senada dengan itu menurut Depdiknas (2006, pp. 345-346) salah satu tujuan pembelajaran matematika SMP adalah melakukan manipulasi matematika dalam membuat generalisasi, menyusun bukti, memecahkan masalah yang meliputi kemampuan memahami masalah, merancang model matematika, menyelesaikan model tersebut, dan menafsirkan solusi yang diperoleh. Disebutkan pula bahwa mata pelajaran matematika perlu diberikan kepada semua peserta didik untuk membekali mereka dengan kemampuan berpikir logis, analitis, sistematis, kritis, dan kreatif, serta kemampuan bekerja sama.

Di Indonesia penelitian yang berkaitan tentang HOTS sudah dilakukan oleh berbagai kalangan akademisi. Beberapa di antaranya adalah penelitian terkait soal tes HOTS siswa kelas VIII (Budiman \& Jailani, 2014, p.139); pengembangan perangkat pembelajaran SMP yang berorientasi pada HOTS oleh Apino (2016), dan penerapan HOTS berdasarkan Problem Based Learning yang bertujuan meningkatkan hasil belajar siswa (Widodo \& Kadarwati, 2013, p. 170). Sedangkan untuk di Kabupaten Mamuju belum banyak penelitian tentang HOTS yang dapat memberikan informasi mengenai kemampuan siswa menyelesaikan soal matematika berbasis HOTS. Selain itu, di Kabupaten Mamuju juga HOTS belum cukup dikenal siswa maupun guru. Berdasarkan hasil wawancara dengan beberapa guru matematika SMP di Kabupaten Mamuju, mereka hanya mengenal HOTS sebagai kemampuan menyelesaikan soalsoal yang sulit. Selain itu, menurut guru-guru banyak siswa yang tidak mampu mengerjakan soal matematika dengan kategori HOTS. Padahal pada Ujian Nasional (UN) 2015/2016 telah memuat soal berbasis HOTS seperti berikut.

\section{"Tarif Taksi"}

Sebuah kota terdapat dua perusahaan taksi A dan taksi B.

Perusahaan tersebut menawarkan tarif taksi seperti tabel berikut.

\begin{tabular}{|l|c|c|c|c|c|c|}
\hline \multirow{2}{*}{ Tarif (Rp) } & \multicolumn{7}{|c|}{ Jarak (Km) } \\
\cline { 2 - 7 } & Awal (0) & 1 & 2 & 3 & $\ldots$ & 15 \\
\hline Taksi A & 7.000 & 9.500 & 12.000 & 14.500 & $\ldots$ & $\ldots$ \\
\hline Taksi B & 10.000 & 12.000 & 14.000 & 16.000 & $\ldots$ & $\ldots$ \\
\hline
\end{tabular}

Penumpang taksi (konsumen) dapat memilih tarif taksi yang lebih murah. Yunia ingin pergi ke mall yang berjarak $15 \mathrm{~km}$ dari rumahnya. Agar diperoleh biaya yang lebih murah, taksi manakah yang sebaiknya akan digunakan oleh Yunia?
A. Taksi A, karena tarif taksi yang lebih murah
B. Taksi B, lebih murah karena lebih kecil, sehingga akan terus murah
C. Taksi A, karena lebih murah 6 ribu rupiah
D. Taksi B, karena lebih murah 4 ribu rupiah 
Berdasarkan laporan hasil Ujian Nasional tahun pelajaran 2015/2016, pada soal tersebut kemampuan yang diuji adalah peserta didik dapat menyelesaikan soal cerita yang berkaitan dengan grafik fungsi linear (misal tentang tarif taksi). dan persentase penguasaan materi ini di Kabupaten Mamuju sangat rendah (rata-rata 49,28) dibandingkan persentase nasional dengan skor rata-rata 91,43. Oleh sebab itu, HOTS siswa Kabupaten Mamuju perlu untuk ditingkatkan. Salah satu caranya adalah dengan melatih siswa berpikir tinggi sesuai dengan jenjang umurnya, hal ini sesuai dengan Depdiknas (2006, p. 345) yang menyatakan bahwa mata pelajaran matematika diberikan kepada semua siswa untuk membekali mereka dengan kemampuan berpikir logis, analitik, sistematis, kritis, dan kreatif, serta kemampuan bekerja sama. Penelitian terdahulu misalnya Nalurita et al. (2013) telah mengaitkan kemampuan siswa SMP dalam menyelesaikan soal matematika berbasis HOTS pada satu materi saja yaitu materi lingkaran dan hanya pada satu sekolah saja. Selain itu penelitian lain yaitu penelitian Kurniati et al. (2016) telah mendeskripsikan kemampuan berpikir tingkat tinggi siswa SMP dalam menyelesaikan soal berstandar PISA. Oleh karena itu, penelitian ini akan memperluas cakupan materi dengan berpedoman pada materi yang diujikan pada ujian nasional untuk mengetahui kemampuan siswa SMP dalam menyelesaikan soal matematika berbasis HOTS di Kabupaten Mamuju.

Menurut Taksonomi Bloom revisi (Anderson \& Krathwohl, 2015, p. 43) ranah HOTS meliputi: (1) menganalisis yang merupakan kemampuan berpikir dalam mengurai atau menghubungkan keterkaitan unsur-unsur; (2) mengevaluasi yang merupakan kemampuan berpikir dalam mengambil keputusan berdasarkan fakta/informasi; dan (3) mencipta yang merupakan kemampuan berpikir dalam membangun suatu rancangan. Tabel 1 menyajikan indikator HOTS dalam penelitian ini.

Tabel 1. Indikator HOTS

\begin{tabular}{lll}
\hline Aspek & Indikator & Sub Indikator \\
\hline Berpikir Kritis & Menganalisis & Membedakan \\
& & Mengorganisasikan \\
& Mengevaluasi & Memeriksa \\
Berpikir Kreatif & Mencipta & Mengkritik \\
& & Merumuskan \\
& & Merencanakan \\
\hline
\end{tabular}

Tabel 1 merupakan acuan dalam mengelompokkan HOTS siswa kabupaten Mamuju. Setelah menyelesaikan soal matematika berbasis HOTS, siswa akan melalui proses tahapan pemecahan masalah yang dimiliki tiga indikator menurut taksonomi Bloom revisi yaitu menganalisis, mengevaluasi, dan mencipta.

Berdasarkan latar belakang masalah dan kajian teori yang telah dikemukakan, maka penelitian bertujuan untuk mendeskripsikan kemampuan siswa SMP di Kabupaten Mamuju dalam menyelesaikan soal matematika berbasis Higher Order Thinking Skills (HOTS).

\section{METODE}

Penelitian ini adalah penelitian deskriptif dengan tujuan untuk mengungkap kemampuan siswa SMP dalam menyelesaikan soal matematika berbasis HOTS. Penelitian dilaksanakan pada kelas VIII dari empat SMP Negeri Kabupaten Mamuju Provinsi Sulawesi Barat, yaitu SMP Negeri 1 Mamuju, SMP Negeri 2 Mamuju, SMP Negeri 1 Kalukku, dan SMP Negeri 1 Papalang. Ukuran sampel penelitian dipilih berdasarkan banyaknya populasi yang ada (Riduwan, 2015, p. 65) sebagai berikut.

$$
n=\frac{N}{N d^{2}+1}
$$

di mana $n$ merupakan ukuran sampel, $N$ merupakan banyaknya populasi, dan $d^{2}$ merupakan tingkat presisi. Sampel minimal dari populasi dalam penelitian ini (menggunakan tingkat presisi $10 \%$ ) yaitu:

$$
\begin{aligned}
& n=\frac{N}{N d^{2}+1} \\
& n=\frac{4626}{4626(0,1)^{2}+1}
\end{aligned}
$$


$n=\frac{4626}{47,26}$

$n=97,88=98$ (dibulatkan ke atas)

Berdasarkan perhitungan tersebut, maka ditentukan 98 siswa yang menjadi subjek penelitian. Siswasiswa tersebut berasal dari empat SMP di Kabupaten Mamuju yaitu: 26 siswa SMP Negeri 1 Mamuju, 32 siswa SMP Negeri 2 Mamuju, 20 siswa SMP Negeri 1 Kalukku, dan 20 siswa SMP Negeri 1 Papalang. Keseluruhan subjek adalah siswa kelas VIII yang telah mempelajari materi-materi yang akan diujikan.

Data pada penelitian ini didapat dari hasil tes kemampuan siswa dalam menyelesaikan soal matematika berbasis HOTS yang terdiri dari soal pilihan ganda dan uraian. Kemudian data hasil tersebut digunakan sebagai pedoman pemilihan subjek untuk wawancara mendalam yang dilakukan kepada unit subjek penelitian dengan mengambil masing-masing tiga siswa dari tiap sekolah. Kemampuan kognitif siswa SMP di Kabupaten Mamuju dianalisis berdasarkan standar kemampuan yang diujikan dalam soal matematika berbasis HOTS. Data yang ada ditabulasi secara deskriptif kuantitatif, yaitu mengadakan penafsiran data berdasarkan perhitungan ketercapaian skor untuk masing-masing butir soal yang dihitung menggunakan rumus berikut.

$$
P=\frac{\sum B}{\sum T} \times 100 \%
$$

di mana $P$ merepresentasikan persentase ketercapaian skor, $\sum B$ merepresentasikan jumlah skor jawaban siswa, dan $\sum T$ merepresentasikan skor total ideal. Setelah data skor ditabulasi berdasarkan level kemampuan yang ditetapkan dan berdasarkan masing-masing indikator, selanjutnya data disajikan dengan mendeskripsikan rata-rata kemampuan siswa menyelesaikan soal HOTS.

Data kuantitatif yang berupa rata-rata skor kemampuan siswa menyelesaikan soal matematika berbasis HOTS dikonversikan untuk menentukan kategori kemampuan siswa dengan acuan normatif simpangan baku yang diadaptasi dari Ebel dan Frisbie (1986, p. 280) seperti pada Tabel 2. Tabel 2 akan digunakan sebagai acuan untuk penggolongan kemampuan siswa dalam menyelesaikan soal matematika berbasis HOTS yang diberikan.

Tabel 2. Kriteria skor kemampuan siswa menyelesaikan soal HOTS

\begin{tabular}{ll}
\hline Interval skor & Kriteria \\
\hline$M_{i}+1,5 S D_{i}<X \leq M_{i}+3 S D_{i}$ & Sangat tinggi \\
$M_{i}+0,5 S D_{i}<X \leq M_{i}+1,5 S D_{i}$ & Tinggi \\
$M_{i}-0,5 S D_{i}<X \leq M_{i}+0,5 S D_{i}$ & Sedang \\
$M_{i}-0,5 S D_{i}<X \leq M_{i}-0,5 S D_{i}$ & Rendah \\
$M_{i}-3 S D_{i}<X \leq M_{i}-1,5 S D_{i}$ & Sangat rendah \\
\hline
\end{tabular}

Keterangan:

$M_{i}=$ rata-rata skor ideal $=\frac{1}{2}($ skor maksimum ideal + skor minimum ideal $)$

$S D_{i}=$ simpangan baku ideal $=\frac{1}{6}($ skor maksimum ideal - skor minimum ideal $)$

$X \quad=$ skor empiris

\section{HASIL DAN PEMBAHASAN}

Pengukuran yang dilakukan pada penelitian ini adalah untuk memperoleh data tentang kemampuan siswa menyelesaikan soal matematika berbasis HOTS. Soal matematika berbasis HOTS tersebut terdiri dari 15 soal, 10 soal pilihan ganda dan 5 soal uraian. Deskripsi perolehan nilai tes soal matematika berbasis HOTS yang diujikan pada siswa kelas VIII di empat sekolah dapat dilihat pada Tabel 3. Berdasarkan Tabel 3, diperoleh informasi bahwa belum ada siswa yang mampu menyelesaikan dengan tepat keseluruhan soal matematika berbasis HOTS. Kemudian dari 98 siswa yang menjadi subjek penelitian, terdapat siswa yang mendapat nilai tertinggi yakni 55 dari skor maksimal 100, dan terdapat siswa yang memperoleh nilai 12 . 
Jurnal Riset Pendidikan Matematika, 8 (1), 2021 - 87

Myelnawan, Wahyu Setyaningrum

Tabel 3. Deskripsi kemampuan siswa

\begin{tabular}{lr}
\hline Deskripsi & Skor \\
\hline Rata-rata & 30,27 \\
Simpangan baku & 9,32 \\
Nilai tertinggi ideal & 100 \\
Nilai tertinggi & 55 \\
Nilai terendah ideal & 0 \\
Nilai terendah & 12 \\
Banyaknya siswa & 98 \\
\hline
\end{tabular}

Selanjutnya penjabaran data hasil penelitian kemampuan siswa SMP Negeri di Kabupaten Mamuju menyelesaikan soal matematika berbasis HOTS dilihat dari kriteria sangat tinggi, tinggi, sedang, rendah dan sangat rendah disajikan pada Tabel 4.

Tabel 4. Distribusi kemampuan siswa dalam menyelesaikan soal matematika berbasis HOTS

\begin{tabular}{llcc}
\hline Skor $(X)$ & Kriteria & Frekuensi & Persentase $(\%)$ \\
\hline $75<X \leq 100$ & Sangat tinggi & 0 & 0 \\
$58<X \leq 75$ & Tinggi & 0 & 0 \\
$42<X \leq 58$ & Sedang & 11 & 11 \\
$25<X \leq 42$ & Rendah & 57 & 58 \\
$0<X \leq 25$ & Sangat rendah & 30 & 31 \\
\hline
\end{tabular}

Dari Tabel 4, diperoleh informasi bahwa tidak ada siswa yang berada pada kategori sangat tinggi dan tinggi. Sebagian besar siswa (58\%) berada pada kategori rendah dan $31 \%$ siswa pada kategori sangat rendah. Hanya 11 dari 98 siswa atau 11\% siswa pada kategori sedang. Dilihat dari rata-rata nilai sebesar 30,27 pada Tabel 3 dan sebaran data pada Tabel 4, dapat dimaknai bahwa kemampuan sebagian besar siswa SMP di Kabupaten Mamuju dalam menyelesaikan soal matematika berbasis HOTS berada pada level rendah.

Selain dideskripsikan berdasarkan kemampuan, kemampuan siswa dalam menyelesaikan soal matematika berbasis HOTS juga dideskripsikan berdasarkan bentuk soal pilihan ganda dan soal uraian. Tabel 5 menyajikan persentase kemampuan siswa dalam menyelesaikan soal matematika berbasis HOTS pada soal bentuk pilihan ganda dan uraian.

Tabel 5. Distribusi kemampuan siswa berdasarkan bentuk soal

\begin{tabular}{lcccccc}
\hline \multirow{3}{*}{ Bentuk soal } & \multicolumn{5}{c}{ Kriteria } & Jumlah (\%) \\
\cline { 2 - 6 } & $\begin{array}{c}\text { Sangat } \\
\text { tinggi }(\%)\end{array}$ & $\begin{array}{c}\text { Tinggi } \\
(\%)\end{array}$ & Sedang $(\%)$ & Rendah (\%) & $\begin{array}{c}\text { Sangat } \\
\text { rendah (\%) }\end{array}$ & \\
\hline Pilihan ganda & 0 & 9,18 & 12,25 & 51,02 & 27,55 & 100 \\
Uraian & 0 & 1,02 & 3,06 & 42,86 & 53,06 & 100 \\
\hline
\end{tabular}

Berdasarkan Tabel 5, diperoleh informasi bahwa dari 98 siswa, sebagian besar siswa memiliki kemampuan rendah dalam menyelesaikan soal bentuk pilihan ganda dan sebagian besar siswa memiliki kemampuan sangat rendah dalam menyelesaikan soal bentuk uraian. Jadi dapat diartikan semua soal yang diberikan kepada siswa sulit untuk diselesaikan. Namun, jika dilihat dari bentuk soal, sebagian besar siswa mengalami kesulitan dalam menyelesaikan soal bentuk uraian $(53,06 \%)$. Data tersebut adalah data keseluruhan dari semua sekolah yang dijadikan sampel penelitian.

Untuk melihat secara rinci perolehan dari tiap sekolah untuk masing-masing bentuk soal, Tabel 6 menyajikan distribusi frekuensi kemampuan siswa dalam menyelesaikan soal matematika berbasis HOTS pada tiap sekolah untuk soal pilihan ganda. Berdasarkan Tabel 6 terlihat bahwa tidak ada sekolah yang mempunyai siswa dengan kemampuan pada kategori sangat tinggi. Pada bentuk soal pilihan ganda ini terlihat bahwa untuk keempat sekolah sebagian besar siswa berada pada kriteria rendah, yaitu SMPN 2 Mamuju 40,63\% siswa, SMPN 1 Kalukku 80\% siswa, dan SMPN 1 Papalang 55\% siswa. Sedangkan di SMPN 1 Mamuju siswa yang berada pada kriteria sangat rendah yaitu sebanyak 50\%. Dari Tabel 6 
dapat disimpulkan bahwa kemampuan siswa menyelesaikan soal matematika berbasis HOTS pada bentuk soal pilihan ganda masih berada pada kemampuan kriteria rendah.

Tabel 6. Distribusi kemampuan siswa menyelesaikan soal pilihan ganda

\begin{tabular}{|c|c|c|c|c|c|c|c|c|c|c|c|c|}
\hline \multirow{3}{*}{ Nama sekolah } & \multicolumn{10}{|c|}{ Kriteria } & \multirow{3}{*}{ Jumlah } & \multirow{3}{*}{$\%$} \\
\hline & \multicolumn{2}{|c|}{$\begin{array}{c}\text { Sangat } \\
\text { tinggi }\end{array}$} & \multicolumn{2}{|c|}{ Tinggi } & \multicolumn{2}{|c|}{ Sedang } & \multicolumn{2}{|c|}{ Rendah } & \multicolumn{2}{|c|}{$\begin{array}{l}\text { Sangat } \\
\text { rendah }\end{array}$} & & \\
\hline & $f$ & $\%$ & $f$ & $\%$ & $f$ & $\%$ & $f$ & $\%$ & $f$ & $\%$ & & \\
\hline SMPN 1 Mamuju & 0 & 0 & 1 & 3,85 & 2 & 7,69 & 10 & 38,46 & 13 & 50 & 26 & 100 \\
\hline SMPN 2 Mamuju & 0 & 0 & 4 & 12,5 & 7 & 21,87 & 13 & 40,63 & 8 & 25 & 32 & 100 \\
\hline SMPN 1 Kalukku & 0 & 0 & 3 & 15 & 1 & 5 & 16 & 80 & 0 & 0 & 20 & 100 \\
\hline SMPN 1 Papalang & 0 & 0 & 1 & 5 & 2 & 10 & 11 & 55 & 6 & 30 & 20 & 100 \\
\hline
\end{tabular}

Data kemampuan siswa dalam menyelesaikan soal matematika berbasis HOTS bentuk soal uraian ditunjukkan pada Tabel 7.

Tabel 7. Distribusi kemampuan siswa menyelesaikan soal uraian

\begin{tabular}{|c|c|c|c|c|c|c|c|c|c|c|c|c|}
\hline \multirow{3}{*}{ Nama sekolah } & \multicolumn{10}{|c|}{ Kriteria } & \multirow{3}{*}{ Jumlah } & \multirow{3}{*}{$\%$} \\
\hline & \multicolumn{2}{|c|}{$\begin{array}{l}\text { Sangat } \\
\text { tinggi }\end{array}$} & \multicolumn{2}{|c|}{ Tinggi } & \multicolumn{2}{|c|}{ Sedang } & \multicolumn{2}{|c|}{ Rendah } & \multicolumn{2}{|c|}{$\begin{array}{l}\text { Sangat } \\
\text { rendah }\end{array}$} & & \\
\hline & $f$ & $\%$ & $f$ & $\%$ & $f$ & $\%$ & $f$ & $\%$ & $f$ & $\%$ & & \\
\hline SMPN 1 Mamuju & 0 & 0 & 0 & 0 & 1 & 3,85 & 12 & 46,25 & 13 & 50 & 26 & 100 \\
\hline SMPN 2 Mamuju & 0 & 0 & 1 & 3,13 & 2 & 6,25 & 16 & 50 & 13 & 40,63 & 32 & 100 \\
\hline SMPN 1 Kalukku & 0 & 0 & 0 & 0 & 0 & 0 & 12 & 60 & 8 & 40 & 20 & 100 \\
\hline SMPN 1 Papalang & 0 & 0 & 0 & 0 & 0 & 0 & 2 & 10 & 18 & 90 & 20 & 100 \\
\hline
\end{tabular}

Berdasarkan Tabel 7 diperoleh informasi bahwa kemampuan sebagian besar siswa di Kabupaten Mamuju dalam menyelesaikan soal matematika berbasis HOTS untuk soal uraian yang diberikan masih dalam kriteria sangat rendah. Tidak ada sekolah yang berada pada kriteria sangat tinggi, dan masingmasing ada dua sekolah berada pada kriteria rendah dan sangat rendah. SMPN 2 Mamuju dan SMPN 1 Kalukku berada pada kriteria rendah, sedangkan SMPN 1 Mamuju dan SMPN 1 Papalang berada pada kriteria sangat rendah.

Selanjutnya frekuensi dan persentase kemampuan siswa dalam menyelesaikan soal matematika berbasis HOTS pada setiap kriteria kemampuan yang dikaitkan dengan indikator HOTS disajikan pada Tabel 8 .

Tabel 8. Distribusi kemampuan siswa menyelesaikan soal untuk tiap indikator HOTS

\begin{tabular}{lcccccccccc}
\hline \multirow{2}{*}{ Indikator HOTS } & \multicolumn{10}{c}{ Kriteria } \\
\cline { 2 - 12 } & \multicolumn{1}{c}{ Sangat tinggi } & \multicolumn{1}{c}{ Tinggi } & \multicolumn{2}{c}{ Sedang } & \multicolumn{2}{c}{ Rendah } & \multicolumn{2}{c}{ Sangat rendah } \\
\cline { 2 - 12 } & $f$ & $\%$ & $f$ & $\%$ & $f$ & $\%$ & $f$ & $\%$ & $f$ & $\%$ \\
\hline Menganalisis & 6 & 6,1 & 17 & 17,3 & 33 & 33,7 & 27 & 27,6 & 15 & 15,3 \\
Mengevaluasi & 0 & 0 & 0 & 0 & 14 & 14,3 & 32 & 32,7 & 52 & 53,1 \\
Mencipta & 0 & 0 & 1 & 1 & 3 & 3,1 & 19 & 19 & 75 & 76,5 \\
\hline
\end{tabular}

Berdasarkan Tabel 8, diperoleh informasi bahwa kemampuan dari 98 siswa di Kabupaten Mamuju dalam menyelesaikan soal matematika berbasis HOTS pada tiap indikator HOTS sebagian besar siswa memiliki kemampuan sangat rendah. Hal ini terlihat dari kemampuan menganalisis dan mencipta yang berada pada kriteria sangat rendah, sedangkan kemampuan menganalisis berada pada kriteria sedang. Untuk lebih jelasnya akan disajikan jawaban per indikator masing-masing soal, indikator yang dimaksud adalah menganalisis, mengevaluasi, dan mencipta. Pada Tabel 9 disajikan persentase jawaban siswa pada indikator menganalisis.

Tabel 9 menunjukkan bahwa pada indikator menganalisis ini sebagian besar jawaban siswa adalah jawaban salah. Hal tersebut terlihat dari 6 butir soal yang ada pada indikator menganalisis ini, ada 3 butir soal yang dijawab salah oleh siswa dengan persentase di atas 63\%. Sedangkan 3 butir soal yang lainnya dijawab benar oleh siswa tapi persentasenya di bawah 63\%. Jawaban salah tertinggi ada di butir soal 15 pada sub indikator mengorganisasikan tapi jawaban benar tertinggi juga ada pada sub indikator 
Jurnal Riset Pendidikan Matematika, 8 (1), 2021 - 89

Myelnawan, Wahyu Setyaningrum

Tabel 9. Distribusi jawaban siswa pada indikator menganalisis

\begin{tabular}{|c|c|c|c|c|c|c|c|c|c|}
\hline \multirow{3}{*}{$\begin{array}{l}\text { Sub indikator } \\
\text { menganalisis }\end{array}$} & \multirow{3}{*}{$\begin{array}{l}\text { Nomor } \\
\text { soal }\end{array}$} & \multicolumn{6}{|c|}{ Jawaban } & \multirow{2}{*}{\multicolumn{2}{|c|}{ Jumlah }} \\
\hline & & \multicolumn{2}{|c|}{ Benar } & \multicolumn{2}{|c|}{ Salah } & \multicolumn{2}{|c|}{ Tidak menjawab } & & \\
\hline & & $f$ & $\%$ & $f$ & $\%$ & $f$ & $\%$ & $f$ & $\%$ \\
\hline \multirow{3}{*}{ Membedakan } & 1 & 53 & 54,1 & 45 & 45,9 & 0 & 0 & 98 & 100 \\
\hline & $14 \mathrm{a}$ & 27 & 27,6 & 63 & 64,3 & 8 & 8,2 & 98 & 100 \\
\hline & $14 \mathrm{~b}$ & 3 & 3,1 & 72 & 73,5 & 23 & 23,5 & 98 & 100 \\
\hline \multirow{3}{*}{ Mengorganisasikan } & 5 & 51 & 52 & 47 & 48 & 0 & 0 & 98 & 100 \\
\hline & 9 & 61 & 62,2 & 36 & 36,7 & 1 & 1 & 98 & 100 \\
\hline & 15 & 1 & 1 & 86 & 87,8 & 11 & 11,2 & 98 & 100 \\
\hline
\end{tabular}

mengorganisasikan pada butir soal 9. Pada sub indikator membedakan dua butir soal jawaban salah tertinggi mempunyai persentase lebih besar dari jawaban benar tertinggi. Dilihat dari kriteria kemampuan menganalisis pada Tabel 8 dan persentase jawaban siswa pada Tabel 9, dapat diartikan bahwa siswa SMP di Kabupaten Mamuju memiliki kemampuan menganalisis yang sedang dengan kesulitan pada indikator membedakan dan mengorganisasikan dalam menyelesaikan soal matematika berbasis HOTS.

Data pada penelitian ini menunjukkan bahwa pada indikator menganalisis (analyze) sebagian besar siswa SMP di Kabupaten Mamuju sudah mampu dalam membedakan (differentiating), hal ini dapat dilihat dari sebagian besar siswa yang sudah mampu dalam memahami informasi yang ada pada soal walaupun belum mampu mengaitkannya dengan baik dikarenakan kesulitan memahami konsep. Namun, sebagian besar siswa masih mengalami kesulitan mengorganisasikan (organizing), hal ini dapat dilihat dari tidak mampunya siswa memilah-milah (mengorganisasi) informasi yang ada pada soal. Setelah dikonfirmasi melalui wawancara, sebagian besar siswa mampu menganalisis suatu permasalahan dengan baik. Selanjutnya untuk indikator mengevaluasi, ditunjukkan pada Tabel 10.

Tabel 10. Distribusi jawaban siswa pada indikator mengevaluasi

\begin{tabular}{lccccccccc}
\hline \multirow{2}{*}{$\begin{array}{l}\text { Sub indikator } \\
\text { menganalisis }\end{array}$} & \multirow{2}{*}{$\begin{array}{c}\text { Nomor } \\
\text { soal }\end{array}$} & \multicolumn{9}{c}{ Benar } & \multicolumn{3}{c}{ Sawaban } & \multicolumn{2}{c}{ Tidak menjawab } & \multirow{2}{*}{ Jumlah } \\
\cline { 3 - 9 } & & $f$ & $\%$ & $f$ & $\%$ & $f$ & $\%$ & $f$ & $\%$ \\
\hline Memeriksa & 3 & 17 & 17,3 & 76 & 77,6 & 5 & 5,1 & 98 & 100 \\
& 7 & 5 & 5,1 & 91 & 92,9 & 2 & 2 & 98 & 100 \\
& 10 & 66 & 67,3 & 30 & 30,6 & 2 & 2 & 98 & 100 \\
Mengkritik & 6 & 24 & 24,5 & 71 & 72,4 & 3 & 3,1 & 98 & 100 \\
& $12 \mathrm{~b}$ & 0 & 0 & 41 & 41,8 & 57 & 58,2 & 98 & 100 \\
& 13 & 2 & 2 & 88 & 89,8 & 8 & 8,2 & 98 & 100 \\
\hline
\end{tabular}

Tabel 10 menunjukkan bahwa jawaban salah tertinggi ada pada sub indikator memeriksa dan pada semua butir soal pada indikator mengevaluasi ini ada jawaban yang kosong atau siswa tidak menjawab dengan persentase tertinggi ada pada sub indikator mengkritik. Hal ini menunjukkan bahwa butir-butir soal pada kemampuan mengevaluasi ini sulit untuk dijawab oleh siswa. Dengan melihat kriteria kemampuan menganalisis pada Tabel 8 dan persentase jawaban siswa pada Tabel 10, dapat diartikan bahwa siswa SMP di Kabupaten Mamuju memiliki kemampuan mengevaluasi yang sangat rendah dengan kesulitan pada indikator memeriksa dan mengkritik dalam menyelesaikan soal matematika berbasis HOTS.

Tabel 11 menunjukkan persentase jawaban siswa dalam menyelesaikan soal matematika berbasis HOTS pada indikator mencipta. Berbeda dengan indikator menganalisis dan mengevaluasi, pada indikator mencipta yang ditunjukkan pada Tabel 11, semua sub indikator sebagian besar jawaban siswa adalah jawaban salah. Hal tersebut dibuktikan dengan semua butir soal menunjukkan persentase tertinggi ada pada jawaban salah. Berdasarkan kriteria kemampuan menganalisis pada Tabel 4 dan persentase jawaban siswa pada Tabel 11, dapat diartikan bahwa siswa SMP di Kabupaten Mamuju memiliki kemampuan mencipta yang sangat rendah dengan kesulitan pada indikator merumuskan, merencanakan, dan memproduksi dalam menyelesaikan soal matematika berbasis HOTS. Berdasarkan data Tabel 8 
Jurnal Riset Pendidikan Matematika, 8 (1), 2021 - 90

Myelnawan, Wahyu Setyaningrum

Tabel 11. Distribusi jawaban siswa pada indikator mencipta

\begin{tabular}{lccccccccc}
\hline \multirow{2}{*}{$\begin{array}{l}\text { Sub indikator } \\
\text { menganalisis }\end{array}$} & \multirow{2}{*}{$\begin{array}{c}\text { Nomor } \\
\text { soal }\end{array}$} & \multicolumn{9}{c}{ Benar } & \multicolumn{9}{c}{ Salah } & Tidak menjawab & \multirow{2}{*}{ Jumlah } \\
\cline { 2 - 9 } & & $f$ & $\%$ & $f$ & $\%$ & $f$ & $\%$ & $f$ & $\%$ \\
\hline \multirow{2}{*}{ Merumuskan } & 11 & 0 & 0 & 98 & 100 & 0 & 0 & 98 & 100 \\
& $14 \mathrm{c}$ & 1 & 1 & 67 & 68,4 & 30 & 30,6 & 98 & 100 \\
\multirow{3}{*}{ Merencanakan } & 2 & 16 & 16,3 & 78 & 79,6 & 4 & 4,1 & 98 & 100 \\
& 4 & 12 & 12,2 & 80 & 81,6 & 6 & 6,1 & 98 & 100 \\
\multirow{2}{*}{ Memproduksi } & 8 & 37 & 37,8 & 51 & 52 & 10 & 10,2 & 98 & 100 \\
& $12 \mathrm{a}$ & 0 & 0 & 62 & 63,3 & 36 & 36,7 & 98 & 100 \\
& $12 \mathrm{c}$ & 2 & 2 & 38 & 38,8 & 58 & 59,2 & 98 & 100 \\
\hline
\end{tabular}

sampai dengan Tabel 11 dapat disimpulkan bahwa kemampuan siswa SMP di Kabupaten Mamuju dalam menyelesaikan soal matematika berbasis HOTS masih dalam pada kriteria rendah.

Selain data tersebut, untuk dapat mengetahui kemampuan siswa dalam menyelesaikan soal matematika berbasis HOTS maka peneliti melakukan wawancara kepada 3 responden dari masing-masing sekolah yaitu: SMPN 1 Mamuju adalah siswa SH7,SH22, dan SH25; SMPN 2 Mamuju adalah siswa SH28, SH42, dan SH58; SMPN 1 Kalukku adalah siswa SH71, SH73, dan SH76; dan SMPN 1 Papalang adalah siswaSH84, SH93, dan SH94. Jadi, total siswa untuk diwawancara ada 12 orang. Kedua belas unit subjek penelitian itu diwawancara secara mendalam untuk mendapatkan informasi secara rinci mengenai kemampuan siswa dalam menganalisis, mengevaluasi, dan mencipta ketika menyelesaikan soalsoal HOTS .

Secara umum, dari kedua belas siswa yang diwawancara, siswa menganggap bahwa soal nomor 1 sampai 15 adalah soal yang rumit untuk diselesaikan dengan berbagai macam kendala. Ketika ditanyakan kepada siswa bagaimana mereka menentukan informasi apa saja yang ada pada soal tersebut, secara keseluruhan kedua belas siswa yang ditanya sebagian besar siswa dapat menyebutkan apa yang diketahui dan ditanyakan pada soal. Walaupun sebagian kecil dari mereka belum mampu mengaitkan informasi untuk menyelesaikan masalah.

Seperti pada soal nomor 14, anak dengan tinggi $150 \mathrm{~cm}(1,5 \mathrm{~m})$, jarak anak dari tiang bendera 12 $\mathrm{m}$, dan jarak kepala dengan puncak tiang bendera $13 \mathrm{~m}$ merupakan hal yang diketahui. Sedangkan tinggi tiang bendera itu merupakan hal yang ditanya, soal inilah sebagian besar siswa yang mampu untuk menjawabnya dengan baik. Tetapi, setelah siswa diminta untuk mengaitkan apa yang sudah diketahui dan ditanya untuk dibuat gambar/sketsa, siswa yang tidak mampu membuat sketsa secara utuh. Mereka membuat sketsa secara terpisah-pisah tanpa membuat garis penghubung yang menyatakan jarak tiang bendera dengan siswa dan jarak puncak tiang dengan kepala siswa. Oleh karena itu, siswa tidak mampu membuat sketsa dengan baik sebab kurang memperhatikan keterkaitan informasi karena sulit memahami konsep garis dan jarak. Hal ini dapat dilihat dari ungkapan siswa sebagai berikut: "saya tidak tahu tentang soal ini, sulit soalnya Pak" (siswa SH84); "saya keliru kalau yang dimaksud jarak kepala anak dengan puncak tiang bendera seperti itu" (siswa SH71); "saya tidak perhatikan yang diketahui satu itu" (siswa SH84, SH93, dan SH94); "o, ternyata begitu ya, saya cepat-cepat mengerjakannya" (siswa SH28 dan SH58).

Dari tiga butir soal kemampuan membuat kesimpulan yang tepat berdasarkan informasi dari suatu situasi/masalah, pada butir soal nomor 5 dan 9 sebagian besar siswa dapat menjelaskan dengan baik tentang cara mereka membuat kesimpulan dari berdasarkan informasi yang ada pada soal. Tapi pada butir soal nomor 15 sebagian besar siswa tidak mampu untuk menyimpulkan dengan baik. Pada butir soal nomor 5, sebagian besar siswa mampu membagi-bagi atau menstruktur informasi yang ada pada gambar dengan baik, mereka mampu menjelaskan pada timbangan 1 bahwa berat 1 kubus $=$ berat 2 silinder + berat 1 bola. Demikian juga pada timbangan 2 bahwa berat 1 silinder $=$ berat 2 bola, soal ini mengharuskan siswa mencari banyaknya silinder agar setimbang dengan berat 2 kubus +2 silinder. Dengan analisis yang mereka lakukan pada timbangan 1 dan timbangan 2 maka siswa akan memperoleh jawaban yang benar. Hanya sebagian kecil siswa yang keliru dalam menentukan banyaknya silinder karena tidak mampu menganalisis atau mengorganisasikan informasi yang ada pada soal tersebut. Hal yang sama juga ditunjukkan pada butir soal nomor 9, siswa sebagian besar mampu menjelaskan dalam membagi-bagi (mengorganisasikan) informasi dengan baik, mereka menjelaskan bahwa tren impor 
handphone setiap tahunnya mengalami kenaikan 5 ribu dan tren impor tablet mengalami kenaikan 10 ribu. Hal tersebut diperoleh kemampuan menganalisis yang pada informasi yang diberikan yaitu pada tahun 2015 impor handphone $=65$ ribu dan tablet $=60$ ribu, pada tahun 2016 impor handphone $=70$ ribu dan tablet $=70$ ribu. Ketidakmampuan membaca grafik dengan baik adalah faktor yang menyebabkan kesalahan siswa pada soal ini.

Berbeda dengan butir soal nomor 15, pada sebagian besar siswa tidak mampu menjelaskan cara untuk membuat diagram lingkaran yang diminta pada soal tersebut. Mereka hanya mampu menyebutkan informasi yang ada pada masalah yang diberikan. Banyaknya kantong golongan darah A ada 15 stok, golongan darah $\mathrm{B}$ ada 20 stok, golongan darah $\mathrm{O}$ ada 35 stok, dan golongan darah $\mathrm{AB}$ ada 10 stok. Mereka tidak mampu untuk mencari nilai masing-masing stok darah dalam derajat atau menghitung perbandingan senilai setiap stok darah yang akan untuk membantu mereka dalam membuat diagram lingkaran. Nilai stok darah dalam derajat tersebut diperoleh dengan membagi nilai masing-masing stok golongan darah dengan jumlah keseluruhan stok setelah itu dikali $360^{\circ}$ maka diperoleh: banyak stok golongan darah $\mathrm{A}=67,5^{\circ}$; banyak stok golongan darah $\mathrm{B}=90^{\circ}$; banyak stok golongan darah $\mathrm{O}=$ $157,5^{\circ}$; dan banyak stok golongan darah $\mathrm{AB}=45^{\circ}$. Dalam soal ini siswa hanya memperkirakan besar masing-masing juring dalam derajat untuk menggambar diagram, hal ini dikarenakan siswa memiliki kemampuan berhitung yang kurang. Semua hal tersebut di atas dibuktikan dengan ungkapan siswa sebagai berikut: "saya salah dan keliru dengan gambar silinder dan bola itu" (siswa SH7, SH25, SH71, dan SH76); "saya cuma menebak jawaban saja" (SH93 dan SH94); "saya tidak tahu karena materinya sudah lama dipelajari" (SH71 dan SH84); "saya perkirakan saja pak kalau stok golongan darah O tertinggi maka pada diagram stok inilah yang besar daerahnya" (siswa SH42).

Kemampuan mengevaluasi yang terkait dengan kemampuan menemukan konsistensi/inkonsistensi dalam suatu operasi/produk dan menilai suatu operasi/produk yang relevan berdasarkan kriteria/ standar. Pada kemampuan menemukan konsistensi/inkonsistensi dalam suatu operasi/produk sebagian besar siswa terkesan bingung bahkan diam saat diminta untuk menjelaskan bagaimana mereka memperoleh jawaban akhir mereka selain itu juga siswa tidak mampu memeriksa kekonsistenan pernyataanpernyataan yang ada pada soal tersebut. Hal ini disebabkan karena siswa kurang memahami nilai suatu fungsi dan salah menentukan daerah asal. Ada siswa yang menyatakan pernyataan (i) $f(x-4)=$ $f(5)$ benar padahal nilai 5 tidak termasuk pada daerah asal $-4 \leq x \leq 4$, demikian juga untuk pernyataan (iii) bernilai salah sebab $f(4)-7=f(3) \Leftrightarrow 16 \neq 17$ sedangkan pernyataan lain adalah pernyataan yang benar. Kesalahan siswa pada butir soal ini juga terletak pada tidak mampunya siswa dalam menyelesaikan operasi dasar matematika dan tidak memperoleh jawaban akhir yang benar dikarenakan tidak memeriksa kembali pekerjaan mereka, buktinya mereka bisa setelah diarahkan untuk menyelesaikan soal tersebut. Beberapa hal tersebut dibuktikan dengan ungkapan siswa sebagai berikut: "saya tidak tahu dan bingung, pernyataan (i) - (iv) saya tidak bisa selesaikan" (siswa SH28, SH71, SH84, dan SH94); "saya mengerti dengan apa yang diketahui" (siswa SH42 dan SH73). Kemudian juga diketahui bahwa, sebagian besar siswa salah dalam menentukan jenis segitiga setiap pernyataan, walaupun siswa mampu menggambarkan segitiga KLM berdasarkan informasi yang ada pada soal. Mereka tidak memeriksa ulang jawaban pada setiap pernyataan berdasarkan gambar yang mereka buat, seperti pada pernyataan (i) sebagian dari mereka menjawab kalau $\Delta$ MNK itu benar adalah segitiga tumpul padahal itu adalah segitiga siku-siku. Hal-hal tersebut di atas dibuktikan dengan beberapa contoh ungkapan siswa sebagai berikut: "Pak, saya tidak yakin jika $\triangle$ KLM itu tumpul" (siswa SH25 dan SH94); "saya lupa lagi pak dengan yang namanya segitiga lancip itu" (siswa SH28, SH42, dan SH84).

Kemampuan siswa dalam mencipta yang terletak pada memadukan dan menggunakan ide/strategi yang tepat untuk menyelesaikan suatu masalah, dan mengembangkan atau membuat alternatif baru dalam menyelesaikan suatu masalah. Pada kemampuan memadukan ide/strategi untuk menyelesaikan suatu masalah, siswa tidak mampu menjawab dengan baik karena kemampuan berpikir siswa ke kehidupan sehari-hari belum ke konsep matematika dan karena siswa tidak mengetahui rumus apa yang dipakai. Seperti pada butir soal nomor 11, semua siswa tidak mampu mengubah dan mencari hubungan informasi pada soal untuk membuat formula agar dapat menemukan jawaban. Siswa diharapkan mencari keuntungan penjualan mobil I dengan formula harga jual = harga beli + untung yang $20 \%$ dari harga beli, demikian juga halnya untuk mobil II dicari kerugiannya dengan formula harga jual = harga beli rugi yang $20 \%$ dari harga beli. Setelah itu hasilnya dibandingkan untuk mendapatkan jawaban dari pertanyaan soal tersebut. Ini dibuktikan dengan beberapa contoh ungkapan siswa: "Pak Budi rugi karena mobil yang dipakai sudah lama jadi perlu diservice dan dipakai untuk memenuhi kebutuhan sehari- 
hari" (siswa SH42 dan SH94); "saya jawabnya pakai logika, saya tidak pakai rumus" (siswa SH7 dan $\mathrm{SH} 28)$.

Pada kemampuan menggunakan ide atau strategi yang tepat untuk menyelesaikan suatu masalah, sebagian besar siswa tidak mampu menyelesaikan soal, siswa mengalami kesulitan dalam mengerti gambar yang disajikan. Mereka kurang mampu menentukan letak sebuah titik pada garis bilangan sebab bilangan yang diinginkan soal itu adalah bilangan pecahan yaitu $\mathrm{K}=\frac{1}{2}$ dan $\mathrm{L}=\frac{3}{2}$. Ada siswa yang mampu menjelaskan letak titik yang diketahui, ia juga mampu menghitung dengan operasi hitung pecahan tapi tidak mampu menunjukkan dengan tepat letak nilai $\mathrm{M}=\frac{3}{4}$ yang telah diperolehnya pada garis bilangan. Hal ini disebabkan karena siswa tersebut tidak mengetahui urutan bilangan terkecil sampai terbesar dari bilangan yang diketahui dan bilangan yang ditanya. Beberapa hal tersebut dibuktikan dengan beberapa contoh ungkapan siswa sebagai berikut: "saya tidak tahu mengerjakan pak karena saya tidak pernah dapat soal semacam itu" (siswa SH42, SH58, dan SH76); "saya tidak bisa menentukan titik yang dimaksud pada garis bilangan” (siswa SH7, SH22, SH28 dan SH71); “ $\frac{3}{4}$ ini setelah 2 Pak” (siswa SH73).

Selanjutnya pada kemampuan mengembangkan atau membuat alternatif baru dalam menyelesaikan suatu masalah, sebagian besar siswa juga tidak menyelesaikan soal karena tidak mengerti dengan soal tersebut dan juga siswa tidak mampu mencari alternatif jawaban lain selain yang ada pada soal. Hal tersebut disebabkan kebingungan terhadap pertanyaan dan yang informasi yang ada pada soal. Siswa mampu membuat persamaan lain tapi tidak bisa membuktikan kalau persamaan linear yang terbentuk tersebut mempunyai tepat satu persamaan, pada kasus ini semua siswa hanya menebak jawaban saja tanpa disertai alasan yang logis. Hal ini disebabkan karena siswa tidak ketidakmampuan siswa dalam memahami matematika yang berkaitan dengan konsep abstrak, mereka tidak mampu mengembangkan hubungan informasi yang ada pada soal dengan yang ditanyakan. Ini dibuktikan dengan ungkapan siswa sebagai berikut: "saya tidak mengerti soalnya Pak" (siswa SH7, SH28, dan SH93); "saya tidak tahu mencari jawaban lain karena itu sudah lama kami telah pelajari pak" (siswa SH28 dan SH73).

\section{Pembahasan}

Berdasarkan data pada Tabel 6 dan Tabel 7, secara umum kemampuan sebagian besar siswa dalam menyelesaikan soal matematika berbasis HOTS bentuk pilihan ganda berada pada kemampuan rendah. Sedangkan untuk bentuk uraian, persentase terbesar siswa berada pada kemampuan sangat rendah. Sehingga, dapat disimpulkan bahwa kemampuan siswa dalam menyelesaikan soal matematika berbasis HOTS berada pada kemampuan rendah. Hal ini sejalan dengan hasil penelitian yang dilakukan Kurniati et al. (2016) yang menunjukkan bahwa dari 30 siswa tersebut didapatkan bahwa 18 siswa tidak mampu melakukan kemampuan logika dan penalaran, analisis, evaluasi, serta kreasi dengan baik dalam beberapa soal, sehingga tergolong memiliki kemampuan berpikir tingkat tinggi dengan level sedang. Selanjutnya, 12 siswa tidak mampu melakukan kemampuan analisis, evaluasi, kreasi, logika dan penalaran dengan baik dalam menyelesaikan semua soal, sehingga tergolong memiliki kemampuan berpikir tingkat tinggi dengan level rendah (Kurniati et al., 2016)

Jika dilihat dari indikator mengevaluasi (evaluate) sebagian besar siswa SMP di Kabupaten Mamuju belum mampu memeriksa (checking) dan mengkritik (critiquing) dengan baik. Hal ini dikarenakan sebagian besar siswa tidak mampu memeriksa kekonsistenan pernyataan-pernyataan yang ada pada soal untuk memperoleh jawaban akhir dan siswa tidak mampu menilai suatu masalah dengan rumus atau pengetahuan yang telah mereka pelajari sebelumnya. Hal ini didukung oleh penelitian yang sebelumnya diteliti oleh Ayuningtyas dan Rahaju (2013) yang mengungkapkan bahwa siswa berkemampuan tinggi tidak mampu dalam menganalisis (analysis), siswa hanya mampu mengevaluasi (evaluate) yaitu checking dan critiquing. Setelah dikonfirmasi melalui wawancara, sebagian besar siswa mengalami kesulitan dalam menjawab persoalan yang diberikan, tidak mampu mengingat rumus yang telah mereka pelajari dengan alasan lupa.

Pada indikator mencipta (create) sebagian besar siswa SMP di Kabupaten Mamuju belum mampu merumuskan (generating), merencanakan (planning), dan memproduksi (producing) dengan baik dikarenakan sebagian besar siswa tidak mampu memadukan dan menggunakan ide atau cara yang tepat, dan siswa tidak mampu membuat alternatif baru dalam menyelesaikan soal tersebut. Hal ini disebabkan siswa belum mampu membawa persoalan ke konsep matematika, tidak mampu mencari hubungan informasi pada soal untuk membuat formula agar dapat menemukan jawaban, dan siswa tidak mampu 
dalam memahami matematika yang berkaitan dengan konsep abstrak. Setelah dikonfirmasi melalui wawancara, sebagian besar siswa mengalami kesulitan menciptakan atau membuat cara lain untuk menyelesaikan terhadap suatu masalah. Hal ini didukung oleh penelitian Nalurita et al. (2013) yang menyatakan bahwa dalam menyelesaikan soal matematika berbasis HOTS tingkat mencipta pada tahap melakukan rencana penyelesaian, siswa tidak dapat melakukan prosedur yang dikerjakan sehingga tidak menemukan jawaban akhir.

Secara keseluruhan dapat diperoleh informasi berdasarkan hasil wawancara mendalam bahwa kemampuan siswa dalam menyelesaikan soal matematika berbasis HOTS yaitu siswa mempunyai kemampuan matematika yang rendah dalam menyelesaikan soal matematika berbasis HOTS ini sehingga tidak mampu menganalisis, mengevaluasi, dan mencipta dengan baik. Faktor yang berkaitan dengan menganalisis dapat dilihat dari siswa mampu mengidentifikasi informasi yang ada pada soal dengan baik tapi siswa tidak mampu untuk mengaitkan informasi yang ada tersebut. Siswa cenderung terburuburu dan kurang memperhatikan keterkaitan yang ada pada soal tersebut. Karena soal ini dua bentuk, siswa cenderung menebak jawaban pada soal bentuk pilihan ganda dan mereka terlalu fokus pada soal bentuk uraian. Siswa juga melakukan kekeliruan dan lupa materi yang ada sehingga tidak bisa membuat kesimpulan dengan benar.

Hasil penelitian menunjukkan bahwa siswa SMP di Kabupaten Mamuju mempunyai kemampuan rendah dalam menyelesaikan soal HOTS. Namun, tidak menutup kemungkinan bahwa terdapat keterbatasan-keterbatasan yang mempengaruhi hasil penelitian. Salah satu keterbatasan tersebut ada pada butir soal pilihan ganda, soal pilihan ganda yang diberikan memiliki empat alternatif jawaban. Siswa diminta untuk memilih salah satu alternatif jawaban yang telah tersedia dan memberikan penjelasan terhadap soal pilihan ganda tersebut, namun yang terjadi adalah siswa hanya memilih salah satu alternatif jawaban saja. Siswa tidak menuliskan penjelasan jawaban mereka pada lembar soal yang diberikan kepada siswa. Selain hal tersebut di atas, keterbatasan dari penelitian ini pada wawancara mendalam yang hasil wawancara yang kurang maksimal atau tidak sesuai harapan peneliti. Hal ini dikarenakan siswa yang dipilih untuk diwawancarai kurang memberikan informasi secara rinci.

\section{SIMPULAN}

Kemampuan siswa SMP dalam menyelesaikan soal matematika berbasis HOTS di Kabupaten Mamuju termasuk dalam kriteria rendah. Selain itu diketahui bahwa rata-rata siswa mampu pada soal dengan indikator menganalisis. Sedangkan pada indikator mengevaluasi dan mencipta, sebagian besar siswa belum dapat menyelesaikan soal dengan baik. Dengan demikian disarankan kepada guru maupun pihak-pihak terkait untuk merancang suatu program pembelajaran yang berorientasi pada pengembangan HOTS siswa. Selain itu, disarankan juga agar ke depannya dilakukan penelitian pengembangan model atau perangkat pembelajaran yang dapat memfasilitasi siswa untuk mengembangkan HOTS.

\section{DAFTAR PUSTAKA}

Anderson, L. W., \& Krathwohl, D. R. (2015). Kerangka landasan untuk pembelajaran, pengajaran, dan asesmen, Revisi taksonomi pendidikan Bloom (A. Prihantoro, Trans.). Pustaka Pelajar. (Original work published 2001).

Anwar, M. N., Aness, M., Khizar, A., Naseer, M., \& Muhammad, G. (2012). Relationship of creative thinking with the academic achievements of secondary school student. International Interdisciplinary Journal of Education, 1(3), 44-47. http://iijoe.org/v1/IIJE_01_03_12.pdf

Apino, E. (2016). Pengembangan perangkat pembelajaran matematika SMA kelas X semester genap menggunkaan model pembelajaran creative problem solving berorientasi pada higher order thinking skills siswa [Master's thesis, Universitas Negeri Yogyakarta]

Arend, R. I., \& Kilcher, A. (2010). Teaching for student learning: Becoming an accomplished teacher. Routledge.

Ayuningtyas, N., \& Rahaju, E. B. (2013). Proses penyelesaian soal higher order thinking materi aljabar siswa SMP ditinjau berdasarkan kemampuan matematika siswa. Mathedunesa: Journal of Mathematics Education, 2(2), 1-9. https://doi.org/10.26740/mathedunesa.v2n2.p\%25p

Brookhart, S. M. (2010). How to assess higher-order-thinking-skills in your classroom. ASCD. 
Budiman, A., \& Jailani, J. (2014). Pengembangan instrumen asesmen higher order thinking skills (HOTS) pada mata pelajaran matematika SMP kelas VIII semester 1. Jurnal Riset Pendidikan Matematika, 1(2), 139-151. https://doi.org/10.21831/jrpm.v1i2.2671

Butkowski, J., Corrigan, C., Nemeth, T., \& Spencer, L. (1994). Improving student higher-order thinking skills in mathematics [Master's thesis, Saint Xavier University-IRI]. https://files.eric.ed.gov/fulltext/ED383526.pdf

Conklin, W. (2012). Higher order thinking skills to develop 21st century learners. Shell Educational Publishing.

Depdiknas. (2006). Peraturan Menteri Pendidikan Nasional Republik Indonesia Nomor 22 Tahun 2006, tentang Standar Isi untuk Satuan Pendidikan Dasar dan Menengah.

Ebel, R. L., \& Friesbie, D. A. (1986). Essential of educational measurement 4th edition. Prentice-Hall, Inc.

Epstein, R. L., \& Kernberger, C. (2006). Critical thinking (3rd ed.). Thomson Wadsworth

Kemendikbud. (2016). Peraturan Menteri Pendidikan dan Kebudayaan Nomor 21 Tahun 2016 tentang Standar Isi Pendidikan Dasar dan Menengah.

Kurniati, D., Harimukti, R., \& Jamil, N. A. (2016). Kemampuan berpikir tingkat tinggi siswa SMP di Kabupaten Jember dalam menyelesaikan soal berstandar PISA. Jurnal Penelitian dan Evaluasi Pendidikan, 20(2), 142-155. https://doi.org/10.21831/pep.v20i2.8058

Lai, E. R. (2011, June). Critical thinking: A literature review. Research report of Pearson. http://www.pearsonassessment.com

Nalurita, I. V., Sutinah, S., \& Rahaju, E. B. (2013). Profil kemampuan siswa SMP dalam menyelesaikan soal HOT pada materi lingkaran ditinjau dari kemampuan matematika siswa. Mathedunesa: Journal of Mathematics Education, 2(3), 1-8. https://doi.org/10.26740/mathedunesa.v2n3.p\%25p

NCTM. (2000). Principles and standars for school mathematics. National Council of Teachers of Mathematics.

Newmann, F. M., King, M. B., \& Carmichael, D. L. (2007). Authentic instruction and assessment: Common standards for rigor and relevance in teaching academic subjects. State of Iowa Department of Education.

Nitko, A. J., \& Brookhart, S. M. (2011). Educational assessment of student. Pearson.

Orlich, D. C., Harder, R. J., Callahan, R. C., Trevisan, M. S., \& Brow, A. H. (2010). Teaching strategies: A guide to effective intruction (9th ed.). Wadsworth Cengange Learning.

Pillay, L. A. M., Omar, A., Harun, R. N. S., \& Zainal, N. (2016). Issues related to the teaching and learning of higher order thinking skills among TESL student teachers. Proceeding of the 1st English Education International Conference (EEIC) in Conjunction with the 2nd Reciprocal Graduate Research Symposium (RGRS) of the Consortium of Asia-Pacific Education Universities (CAPEU) between Sultan Idris Education University and Syiah Kuala University, 451-456.

Presseisen, B. Z. (1985). Thinking skills: Meaning and models. In A. L. Costa (Ed.), Developing minds: A resource book for teaching thinking (pp. 56-62). ASCD.

Renstein, A., \& Lander, G. H. (1990). Developing critical thinking in college programs. Journal of Scientific Exploration, 4(2), 123-136.

Resnick, L. B. (1992). Education and learning to think. National Academy Press.

Riduwan, R. (2015). Belajar mudah penelitian untuk guru-karyawan dan peneliti pemula. Alfabeta.

Thompson. T. (2012). An analysis of higher-order thinking on algebra i end-of course tests. https://www.cimt.org.uk/journal/thompson.pdf 
Thomas, A., \& Thome, G. (2009, December 9). How to increase higher order thinking. http://www.cdl.org/articles/how-to-increase-high-order-thinking/

Widodo, T., \& Kadarwati, S. (2013). Higher order thinking berbasis pemecahan masalah untuk meningkatkan hasil belajar berorientasi pembentukan karakter siswa. Cakrawala Pendidikan, XXXII(1), 161-171. https://doi.org/10.21831/cp.v5i1.1269

Yee, M. H., Othman, W. bin., Md Yunos, J. Bin., Kiong, T. T., Hassan, R. Bin., \& Mohamad, M. M., Binti. (2011). The level of marzano higher order thinking skills among technical education student. International Journal of Social Science and Humanity, 1( 2), 121-125. https://doi.org/10.7763/IJSSH.2011.V1.20

Yen, T. S., \& Halili, S. H. (2015). Effective teaching of higher-oreder thinking (HOT) in education. The Online Journal of Distance Education and e-Learning, 3(2), 41-47. https://tojdel.net/journals/tojdel/articles/v03i02/v03i02-04.pdf 